\title{
The 2016 National Matriculation and General Certificate of Secondary Education English Test: A Challenge to the Goal of Foreign Languages Education in Vietnamese Schools
}

\author{
Hoang Van Van ${ }^{*}$ \\ VNU University of Languages and International Studies, \\ Pham Van Dong, Cau Giay, Hanoi, Vietnam \\ Received 30 November 2017 \\ Revised 15 December 2016; Accepted 25 December 2017
}

\begin{abstract}
Every year in Vietnam there are nearly a million Vietnamese 12 graders taking as compulsory the national general certificate of secondary education English testto be eligible to receive general certificate of secondary school education. Since 2015, the English test has been used for students to achieve two goals: (1) to receive general certificate of secondary school education and (2) to gain entrance to Vietnamese universities and colleges. The test is referred to as "the national matriculation and general certificate of secondary education English test". It has a clear format, clearly specified contents, a clear and detailed scoring scheme, and is made public in the Vietnamese mass media. However, looked at from both theoretical and practical levels, there are still problems with the test that need to be examined and discussed. This is the purpose of this paper. As a way of start, the paper will provide a description of the test. Then, it will examine some of its key qualities, and present its washback and impact on the Vietnamese general school foreign language education. In the conclusion, after summarizing the strengths and weaknesses of the test, the paper will conclude that due to its weaknesses in both content and format,and its longterm negative washback, the 2016 national matriculation and general certificate of secondary education English test presents a big challenge to the communication goal of the Vietnamese general foreign language education. The paper recommends that for the quality of foreign language teaching and learning in Vietnamese schools to be improved andfor the foreign language education in Vietnamese schools to meet the requirements of globalization in Vietnam, a radical renovation in both test format and test administration should be exercised.
\end{abstract}

Keywords: The 2016 national matriculation and general certificate of secondary education English test.

\section{Introduction}

Over the past decade or so, foreign languages education in Vietnam has made positive changes in terms of policy, theory and practice, and has achieved stimulating results.

\footnotetext{
Tel:

Email: vanhv@vnu.edu.vn

https://doi.org/10.25073/2588-1159/vnuer.4112
}

These achievements are most pronounced in English as a school subject. As mentioned in Hoang Van Van [1-4], the English school curriculaincluding Bộ Giáo dục và Đào tạo (MoET)'s Chuơng trình giáo dục phổ thông môn tiếng Anh (English Curriculum for Vietnamese Schools) [5] which is now being taught and learnt nationwide and MoET's three pilot 10-year English language curriculafor 
schools in Vietnam[6-8] are designed in the direction of the communicative approach, the textbooks of both the seven-year curriculum and the 10-year curriculumare developed in the direction of the communicative approach, the teaching methods are oriented in the direction of the communicative approach, and most recently the three formats of the English language proficiency tests from Level 1 to Level 3 [9-11] based onMoET's Six-level Foreign Language ProficiencyFramework for Vietnam [12] is also designed in the direction of the communicative approach (testing students' ability in listening, speaking, reading and writing). If the testing component in the cycle curriculum $\leftrightarrow \quad$ textbook/material $\leftrightarrow$ teaching/learning $\leftrightarrow$ testingare consistently and synchronously implemented, the teaching and learning of foreign languages in Vietnam in general and the teaching and learning of English in schools in Vietnam in particular will raise fewer problems to discuss. At present there seems to be a big gap between theory and practice of in terms of foreign language testing in schools in Vietnam. Ananalysis of the contents of both formative (one-period and endof-term)summative (end-of-school year) tests from primary to upper secondary levels have revealed that only some primary schools where English is taught as an elective subject, some lower secondary and upper secondary schools in cities and affluent areas, and foreign languages specialized upper secondary schools use communicational tests.The remaining majority of the schools across the country, especially upper secondary schools, use noncommunicative tests (testing students' linguistic competence in phonology, lexis, grammar andone communicative skill - reading skill). Two questions that can be raised here: (1) "Why is testing not aligned with the communicative orientation of curriculum, textbooks, and teaching?", and (2) "What impact/backwash does non-communicative testing have on the communicative goal of foreign languages education in Vietnamese schools in the context of globalization?"In search of an answer to these questions, in this paper an attempt is madeto look at the 2016 National Matriculation and General Certificate of Secondary Education English Test - a test that is said to represent all national matriculation and general certificate of secondary education tests of other foreign languages being taught in schools. The article consists of four main parts. Part 1 - Introduction - providesreasons and the contents the article intends to study. Part 2 describes in some detail the content of the 2016 National Matriculation and General Certificate of Secondary Education English Test. Part 3 discusses some of the main qualities of the test and points out the impacts (both positive and negative) of the test on English language education in schools in Vietnam.Section 4 summarizes the strengths and weaknesses of the test and discusses some additional points related to the test. The paper concludes with the conclusion that due to its drawbacks and negative backwash, the 2016 National Matriculation and General Certificate of Secondary Education English Test has presented a big challenge, hindering the communication goal of foreign language education in Vietnamese schools. It recommends that in order to improve the quality of learning and teaching foreign languages in schools in Vietnamand to meet the requirements of globalization, there should be a radical change in foreign language testing in terms of both test format and test administration.

\section{The 2016 national matriculation and general certificate of secondary education English test}

\subsection{The structure of the 2016 national matriculation and general certificate of secondary education English test}

The 2016 National Matriculation and General Certificate of Secondary Education English Test is one of the most important public 
exams to the Vietnamese society. At the time of writing this article, it is the only one paperbased English test for matriculation and general certificate of secondary educationwhich is applied on a nationwide scale andis held in June everyyear. The test is designed under the direct instruction of the MoET. Before 2015, the test aimed at only one objective: to test English knowledge and skills of 12 graders as part of the requirement for conferring general school certificate. Since 2015, the test has aimed at achievingtwo objectives: (1) to confergeneral school certificate and (2) to be used as a requirementfor admitting candidates to colleges and universities (for details, see Bộ Giáo dục và Đào tạo [MoET][13]).Every year, about one month before the test is held, a number of university lecturers and senior high school English teachers are summoned by MoET to come to design the test. After the design of the test is completed, some of these lecturers and school teachers may be summoned again to come to score the tests. Critical issues of the test such as validity, reliability, fairness, consistency, and format are either not taken into account or are unquestionablyacceptedas the test format and the materials for designing the test are available on their arrival at the testdesigning site. The test is 90 minutes long; all rubrics on the test are in English; candidates write their answers in their answer sheets. The structure of the test is summarized in Table 1 below.

Table 1. Structure of the 2016 national matriculation and general certificate of secondary education English test

\begin{tabular}{lllll}
\hline Contents & Types of items & Number of items & Score/item & Total (\%) \\
\hline & Objective & & & \\
1. Phonology & $(-)$ & 5 & 0.125 & $0.625(6.25 \%)$ \\
$\begin{array}{l}\text { 2. Lexicogrammar } \\
\text { 3. Reading }\end{array}$ & $(-)$ & 27 & 0.125 & $3.375(33.75 \%)$ \\
& $(-)$ & 32 & 0.125 & $4.0(40 \%)$ \\
4. Writing & Subjective & & & \\
Paraphrasing & $(-)$ & 5 & 0.1 & $0.5(5 \%)$ \\
Paragraph writing & $(-)$ & 0 & 1.5 & $1.5(15 \%)$ \\
\hline & 69 & & $10(100 \%)$ \\
\hline
\end{tabular}

Table 1 shows that the 2016 National Matriculation and General Certificate of Secondary Education English Testis designed in four components, two of which are intended to test candidates' English language knowledge in phonology and lexicogrammar; and two others are intended to testtheir English language skills: reading and writing. The test is designed in two modes: objective and subjective. Details of each test component can be presented as follows:

- Phonologyhas 5 items(accounting for $6.25 \%$ of the total score) andis designed in the form of 4 multiple-choice questions. It consists of two parts: Part 1 ( 2 items) asks the candidate to mark the correct option on the answer sheet which indicates the word whose underlined part differs from the other three in pronunciation; Part 2 (3 items) requires the candidate mark thecorrect option on the answer sheet to indicate the word which differs from the other three in the position of primary stress.

- Lexicogrammar (27 items, accounting for $33.75 \%$ of the total score) is designed in the form of 4 multiple-choice questions. This part consists of 3 sections: Section 1 (19 items) asks the candidate to mark the correctoption on the answer sheet for each of the questions; Section 2 (3 items) requires the candidate to mark the answer that is closest in meaning to the underlined word(s) in each question given; and Part 3 requires the candidate to mark the correct 
option on the answer sheet to indicate theunderlined part that needs correction.

- Reading comprehension (32 items, accounting for $40 \%$ of the total score) is designed in the form of 4 multiple-choice questions. This part consists of 4sections: Section 1 (10items) requires the candidate to read a passage and mark the letter A, B, C, or D on the answer sheet to indicate the correct answer to each of the questions given; Section 2 (2items) requires the candidate to mark the letter A, B, C, or D on the answer sheet to indicate the word(s) opposite in meaning to the underlined word(s) in the questions given; Section 3 (10 items) requires the candidate to read a passage and mark the correct answer on the answer sheet to indicate the correct word or phrase that best fits each numbered blanks; and Section 4 (10 items) asks the candidate to mark the letter A, B, C, or D on the answer sheet to indicate the correct answer to each of the questions given.

- Writing (accounting for $20 \%$ of total score) consists of 2 sections: Section 1 (5 items) requires the candidate to rewrite the sentence in a way that it means the same as the original sentence; and Part 2 requires the candidate to write a paragraph of about 140 words with suggestions on the benefits of knowing how to swim.

\subsection{Score and scoringprocedure}

As Table 1 shows, the scores for each item of the 2016 National Matriculation and General Certificate of Secondary Education English Test are clearly specified. Scores of many items are counted to three decimal numbers. For example, in the phonology, lexicogrammar and reading comprehension sections, each item is weighted to 0.125 points. The total scores of the whole test are assigned to the mark 10. The scoring is done by scoring committees (located in provincial departments of education or universities assigned and appointed by MoET. The objective (multiple-choice) items are machine-scored. The subjective components are scored by a group of (human) markers. They are first scored by two (human) markers, and then are checked on the spot by the team leader. Before the scoring, the markers were trained, andthen each pair of markers was assigned sometests to pilot scorethem according to the suggested answers. Then the whole group of markers discusses and adjusts the answers accordingly.

\section{Some qualities of the 2016 national matriculation and general certificate of secondary education English test}

\subsection{Introductory notes}

Many foreign language teachers, especially school foreign language teachers, view testing as something technical which goes beyond their reach. They are often haunted by theoretical models, complex procedures, and abstract discussions by researchers on ambiguous, slippery concepts of test theory (cf. Alderson, $[1,14])$. They find it difficult to talk about what a good test, a useful test (Alderson [14]; Shohamy [15]; Weir [16]), or a fair test (Bachman \& Palmer [17]; Brown [18]; Kunnan $[19,20]$ is.They even panic when it when test scholars say that a good test, a fair test, or a usefulness test must have criteria such as validities specified into face validity, content validity, concurrent validity, construct validity; reliabilities specified into authenticity, interactiveness (Bachman \& Palmer [17]; Bachman [21]; Hughes [22], Kunnan [19, 20], and so on. These concepts, along with the definitions "to clarify" them such as "... a test is said to be valid if it measures accurately what it is intended to measure" (Hughes [22, 26] or" Reliability is defined as the consistency of measurement" (Bachman \& Palmer [17, 19] further alienate teachers, even researchers from the discourse. In fact, according to Alderson [14], these concepts are appropriate because many of them are important for understanding how we design a test and what we are trying to 
doto testour students. The problem lies in the fact that these concepts are often used at the wrong time and in the wrong place, andin particular they donot address the right audience.It seems that whenever and wherever the discourse on testing is presented, it is presented as if a researcher were talking to researchers, not to an audience many of whom arenot so much interested in theoretical issues. For this reason, while examining and discussing the 2016 National Matriculation and General Certificate of Secondary Education English Test, where possible, I will try to avoid using scholarly concepts that are incomprehensible to the general reader (although Iam fully aware that this is not an easy task), especially to school foreign language teachers who are more interested in what they are doing in the classroom than in what they must know about the science of foreign language testing.Specifically, I will discuss and evaluate the following qualities of the 2016 National Matriculation and General Certificate of Secondary Education English Test: (i) representativeness of content, (ii) objectivity, (iii) discrimination power, and (iv) impacts of the test. Note that from now onI shall use the terms "test" and "exam" interchangeably.

3.2. Representativeness of content of the 2016 national matriculation and general certificate of secondary education English test

According to Bachman \& Palmer [17], Alderson [14], and Kunnan [20], a test is considered valid when it meets a number of fundamental criteria of which the criterion of representativenessof content is of special importance. The representativeness of content of the 2016 National Matriculation and General Certificate of Secondary Education English Test is understood as the scope in which the test represents a set of contents that have been taught as defined in MoET's Chuoong trình giáo dục phổ thông môn tiếng Anh (General English Curriculum) [5]. Seen from this point of view, the 2016 National Matriculation and General
Certificate of Secondary Education English Test is expected to meet the criterion of representativenessof content when it contains both language knowledge components (phonetics/phonology, vocabulary and grammar) and language use components (listening, speaking, reading and writing).As described in Section 2.1, in the 2016 National Matriculation and General Certificate of Secondary Education English Test, the language knowledge components are tested through two distinct contents: phonetics/phonology and lexicogrammar, in which phonetics (including 5 items) tests the candidate's ability to discriminate the pronunciation of words and the position of word stress through orthography, lexicogrammar (including 27 items) tests the candidate's ability to use words in contexts, including the ability to detect errors; and the language use component is tested through two skills of reading (32 items) and writing (including 5items)which require the candidate to rewrite the sentence which has the same meaning as the original sentence and write a paragraph of 140-word paragraph about a given topic.Listening and speaking skills are not in the design of the 2016 test (and they have been in the design ofthe tests prior to 2015 as well)

A test used as a requirement forconferring on a candidate general school certificate and for admitting him/her to a college or university should be a sample representing the teaching and learning contents as defined and covered in the curriculum and textbooks. As mentioned above, all the current English curricula for schools in Vietnam: the seven-year General English Education Curriculum [5], the Pilot English Curriculum for Primary Schools in Vietnam [6], the Pilot English Curriculum for Lower Secondary Schools in Vietnam [7], and the Pilot English Curriculum for Upper Secondary Schools in Vietnam [8] have recognised language knowledge (including phonetics, vocabulary and grammar) and language skills (including listening, speaking, reading, and writing) as two basic contents of 
English language teaching and learning. Assuming that the two areas of language knowledge and language skills represent the content validity of a foreign language test, it is possible to assert that the representativeness of content of the 2016 National Matriculation and General Certificate of Secondary Education English Test is not high.The reason is that with the two extremely important goalsit sets for itself (i) as a requirement for conferring onthe candidate general school certificate and for admitting him/her toa college or university, one would expect the time span of the test to be much longer than 90minutes, and the test to contain a wide range of contents and items that are more diverse than the current one, and even to include a number of sub-tests to test the candidate's competences in both language knowledge and language skills. Analysis of the 2016 National Matriculation and General Certificate of Secondary Education English Test shows that its contents only test indirect pronunciation skill (a form of test that although the candidate can identify which option is pronounced differently from the other three, $\mathrm{s} /$ he may still pronounce the identified soundincorrectly), the ability to use wordsand phrases, and the ability to read and write. With such limited content coverage, it is certain that the test is not a representative sample of the English language teaching and learning contents in schools, and therefore its representativeness of content is questioned.

It is possible that the test designers understand the importance of the criterion of "representativeness of content" of a test, but due to prescribed constraints such as the time span of the test (90 minutes), the number items (64) and the two writing sections (one is sentence rewriting and the other is paragraph writing), they cannot translate fully this criterion into the test. They may recognise that a test that is designed to test students' language knowledge and abilities after 7 years of learning in school (with about 700 class hours) has no listening and speaking components will certainly not represent all the contents learnt.However, if these skills are present in the test design, it will be unrealistic and unreasonable. Unrealistic because this is a public test, which is applied nationwide with a huge number of candidates all taking the test at the same time. If a test of this size incorporates both listening and speaking skills in it(and compared to the tests of other school subjects), it will become extremely complex, time-consuming and costly in terms of human resource (a huge number of oral examiners will be required) and financial resource (a big amount of money will be spent on purchasingCD players and preparing $C D$ audio recordings for some thousands of exam rooms only for the listening test sectionwhich lasts for 20-30 minutes). That is not to mention the subjectivity of the examiners while marking candidates' speaking skills. Unreasonable because although all the candidates are 12 graders, their English language proficiency is very different by regions/areas. Students in more economically developed areas such as Hanoi, Ho Chi Minh City, Hai Phong, Da Nang, etc., can have early exposure to English from various sources such as radio, TV, Internet, and other ICT facilities, and, therefore, have better English proficiency. In contrast, students in rural, mountainous, remote and isolated areas are exposed to English much later, and have little or no exposure to English through modern means, and therefore, have lower level of English proficiency.Ifspeaking and listening are present in the test design, students in disadvantaged areas will face with a lot of difficulties, and for this reason the test may lose some of its fairness(cf. Brown [18]; Kunnan $[19,20]$; Shohamy [15]. On the other hand, although the 2016 National Matriculation and General Certificate of Secondary Education English Test contains a component testing the candidate's writing skill, whether this skill should be designed in the test is a matter of debate in Vietnam. Proponents of the view that "writing should not be in the design of the test" argue that although writing is a compulsory component in the curriculum and textbooks, in reality, due to its on and off in the previous test 
designs, writing, especially creative writing (paragraphwriting and essay writing) is rarely taught properly in schools. What students are taught is primarily focused on developing sentence-writing skills such as sentencerewriting and sentence combining (combining two simple sentences into a compound sentence, etc.). In addition, like the scoring of speaking skill, the scoringof writing skill also contains some degree subjectivity on the part the scorer, and thussome degree of reliabilityand validity of the test may be lost. In contrast, advocates of the view that "writingshould be part of the test" argue that the 2016 National Matriculation and General Certificate of Secondary Education English Test only teststwo language skills: reading and writing, now if the writing component is removed from the test, its representativenessof content which has already been challenged will become more challenged. They further argue that the presence of the writing componentin the test will increase both the validityof the test and the positive impact on English language teaching and learning in the classroom: teachers and studentswill pay more attention to teaching and learning writing skills.

\subsection{Objectivenessof the 2016 national matriculation and general certificate of secondary education English test}

The purpose of any test or exam is to ensure that it is reliable so that it can measure exactly what it is supposed to measure (Shohamy [15]; Hughes [22]; Alderson [14]; Kunann [20]). With regard to the 2016 National Matriculation and General Certificate of Secondary Education English Test - a test that aims at achieving two important goals: as a requirement for conferringon the candidate general school certificate and a requirement for admitting $\mathrm{him} /$ her to a college or university, the reliability of the test should be given more prominence. In a test, reliability is first expressed through its objectiveness. The objectiveness of the 2016 National Matriculation and General Certificate of Secondary Education English Testis found in the proportion of the objective itemsto theamount of the non-objective contents. As described in Table 1, the 2016 National Matriculation and General Certificate of Secondary Education English Test is designed in the proportion of $4 / 1 \quad 80 \%$ of the items is designed in multiple-choice mode and the remaining $20 \%$ of the contents is designed in non-objective mode). The objective portion of the test is machine-scored in combination with the non-objective portion beinghuman scored and is checked on the spot by the third (human) scorer.The two modes of objective and nonobjective test, combined with the two forms of machine and human scoring and on-thespotcheckingcan increase the reliability of the test and thus ensuring its objectiveness.

There is a point worth noting here; that is, the 2016 National Matriculation and General Certificate of Secondary Education English Test does not seem to be pretested before being put into use. To compensate for this limitation and to ensure confidentiality, once the test development is completed, one or two English language experiencedteachers are invited by MoET to come to review and to try doingthe test. If this practice is accepted, it can be affirmed that, to a certain extent, the 2016 National Matriculation and General Certificate of Secondary Education English Test has metone more aspect of the reliability criterion.

\subsection{Discrimination powerof the 2016 national matriculation and general certificate of secondary education English test}

As mentioned above, the 2016 National Matriculation and General Certificate of Secondary Education English Testaims not only at conferring on the candidate general school certificate but also at selecting candidates for colleges and universities. In order to serve these two goals, the discrimination power of the test must be of particular concern.As a guide, MoET stipulates that the 2016 National Matriculation and General Certificate of 
Secondary Education English Test must contain $60 \%$ of the items that test the candidate's basic knowledge and skills (to serve the first goal) and $40 \%$ of items to test knowledge and skills of the more advanced candidate (to serve the second goal).

"A good test must yield a good distribution of scores" (Biggs [18, 23]). To be more specific, a good test must yield a diversity of scores, reflecting the correct levelsfrom the best candidate down to the worst candidate. What is meant by this is that the best candidate will receive the highest score, the above average candidate will receivethe above average score, the average candidate will receive the average score, and the worst candidate will receive the poorest score.In order to be able to achieve this criterion, the language knowledge and communication skills of an average candidate must be taken as the point of departure for the design of the test so that, if scored on a scale of 10 , the scores of the average candidates will liesomewhere between of 5 to 6 . To seemore clearly the discrimination power of the 2016 National Matriculation and General Certificate of Secondary Education English Test, let us look at Figure 1 below.

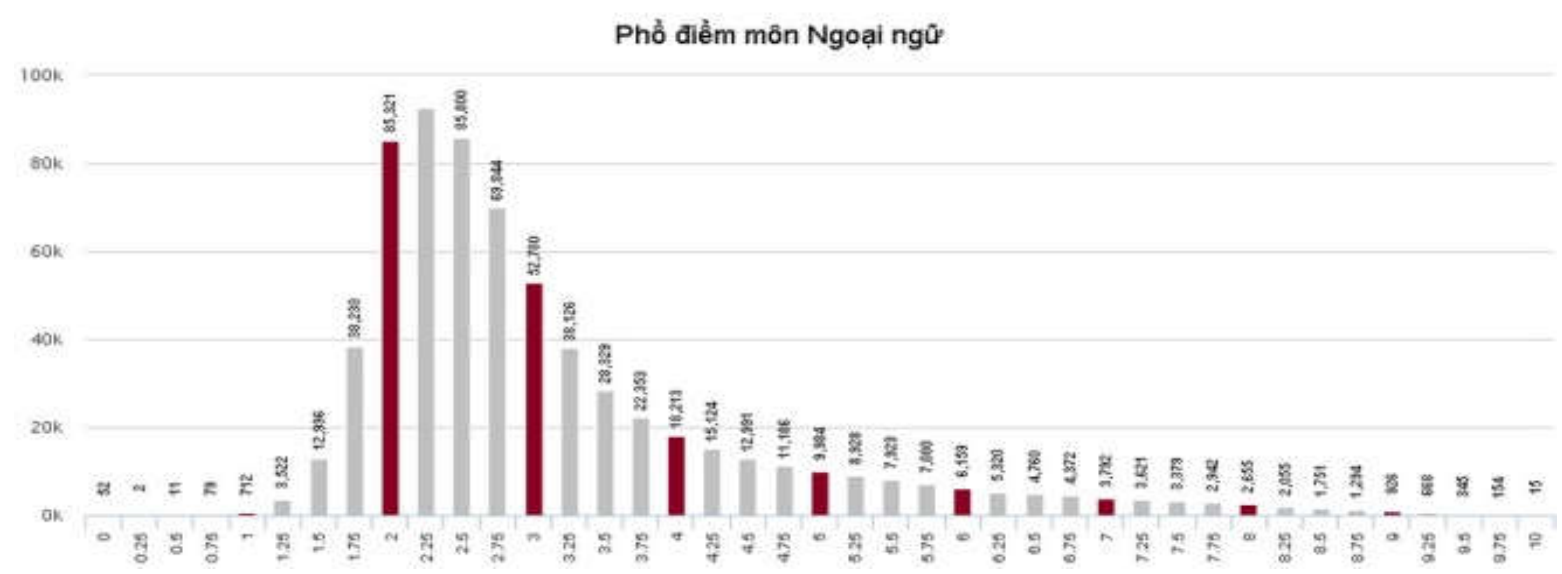

Figure 1. Distribution of scores of the 2016 national matriculation and general certificate of secondary education English test (Source: VnExpress ngày 22 tháng 7 năm 2016 [29]).

Theoretically, an ideal test would produce normal distribution of a bell-curved shape with mean, median, mode and midpointfalling on exactly the same score value (Brown [18, 129], and with variance between 7-8/10. Observing the distribution of scores of the 2016 National Matriculation and General Certificate of Secondary Education English Test, one can see that the scores range from 1 to 9 , in which the bell shape is too much lopsided and "crunched up" (Popham [24] toward the lower end of the scale -the side of the scale inwhich the majority of the test scores are below average. Figure 1 also shows that the low scoresare concentrated in the range of $2-4$, in which the number of scores from 2 to 3 takes up the highest; the number of tests that has "dead scores" (scored from 1 or lower) accounts for about $1 \%$; the number of scores from 5 and above is very low; and in particular, no test has score above 9. In total, about $90 \%$ of the tests are scored below the average, and the average score of all the tests is 3.3 (VnExpress ngày 22 tháng 7 năm 2016 [29]). It can be said from the above results that the discrimination power of the 2016 National Matriculation and General Certificate of Secondary Education English Testis very low.

Likethe 2015 National Matriculation and General Certificate of Secondary Education English Test (see VnExpress, ngày 23 tháng 7 năm 2015 [25], see also Pham Viet Ha [26]), 
the distribution of scores of the 2016 National Matriculation and General Certificate of Secondary Education English Test is abnormal. When a test has an abnormal score distribution beingskewed toward the lower end of the scale, it is likely to be attributedto two common and easily observable factors: teachers (the teachers' knowledge and skills are poor, they do not have the love for teaching English, etc.) and students(the student's learning ability is poor, they do nothave motivation to learn English, and they only learn English to pass exams, etc.). However, there is one equally important factor that often seems to be neglected, or for some hidden reason is not explicitly stated; that is, the test is difficultand the test designers have not yet clearly defined the knowledge and skillstandards which a normal/averagecandidate is required to achieve on finishing the seven-year English programme (of 700 class contact hours in a foreign language environment). Like what Pham Viet Ha [26] has remarked about the 2015 National Matriculation and General Certificate of Secondary Education English Test, analysis of the content design of the 2016 National Matriculation and General Certificate of Secondary Education English Test shows that except for the writing section (In about 140 words, write a paragraph about the benefits of knowing how to swim) the majority of items that are designed to test students' phonological and lexicogrammatical knowledge are difficult even for excellentstudents; all three reading passages are of academicregister, a text style which is alien to most of the students who have been familiarized with general Englishreading texts in their textbooks. What makes matters worse is that all the threereading passages are more difficult than the average student ofthe current seven-year curriculum.To further confirm this statement, Igave the test toa group of 20 excellent 12 graders and let them do the test. ThenImarked the tests and talked to the students. It is clear from the results of the tests and fromwhat the students said me that the test seems to be designed for the excellentrather than for the average 12 grader. It explains why the 2016 National Matriculation and General Certificate of Secondary Education English Testhas an abnormal distribution of scores as displayed in Figure 1.

3.5. Impacts of the 2016 national matriculation and general certificate of secondary education English test

Like many Asian countries, the Vietnamese consider school examsa very important social event. They perceive the general school certificate exam in general and the 2016 National Matriculation and General Certificate of Secondary Education English Test in particular as a manifestation of fairness through which the candidate's score is considered as part of the requirement for obtaining general school certificate and for being admittedto a college or a university regardless of where $\mathrm{s} / \mathrm{he}$ comes from and what his or her social relationships are. Any bias or expression of bias against a candidate or a group of candidates will result in an outrageous response and criticism from the candidates themselves, their parents, and the whole society. Seen from this point of view, the general school certificate exam in general and the 2016 National Matriculation and General Certificate of Secondary Education English Test in particular are of special importance to the society of Vietnam.It explains why every year when the general school certificate exam is held, not only the education sector but also many other sectors in the country are involvedin this important social event: the police, the communication and transport, the youth union, etc. It also explains why every year, while the general school certificate exam isheld, millions of people, including those who are not taking the exam, are also affected by this important social event.Scenes of fathers, mothers, brothers, sisters, and the candidates looking for accommodation; and scenes of fathers, mothers, and relatives waiting for their children or their relatives outside the test sites, desiring their 
children and grandchildren to pass the exam and to be admitted to a college or university have become quite familiar. Traffic congestion for hours in big cities, causing troubles to traffic police and young volunteers has become a common phenomenon. Since 2015, when MoEThas exercised the "two in one" policy, trying to achieve two goals in one test: as a requirement for conferring on the candidate school certificate and as a requirement for admitting him/her to a college ora university, the general school certificate exam in general and the National Matriculation and General Certificate of Secondary Education English Testin particular have become even more important. It affects almost every aspect of foreign language education in schools in Vietnam: students, teachers, schools, and, in particular, the methods of teaching and learning English in the classroom.

3.5.1. Impacts of the National Matriculation and General Certificate of Secondary Education English Testonstudents, teachers and schools

Perhaps students and teachers are the two subjects that are most affected bythe National Matriculation and General Certificate of Secondary Education English Test. With regard to students, the test has a direct impact on their future. If they pass the test, they will be conferred general school certificate and, more importantly, theywill be admitted to a college a university of their choice. In contrast, if they fail the exam, the future ahead of them will be unclear.

The test has similar impact on teachers. The author of this article has conducted a minisurvey by having friendly talks with some upper secondary school teachersof English to find out how the 2016 National Matriculation and General Certificate of Secondary Education English Testimpacts on their lives. When asked, "What impact do the students' scores of the test have on you?", many teachers answered that the students' scores of the test affect almost every aspect of their lives: it is an important, even a decisive criterion for assessing their professional level,their level of emulation, theirchance of promotion, their feeling of success, their status and prestige in the eyes of colleagues, leaders, students, and parents.

Schools and provincial departments of education and training are also affected by the students' scores of the National Matriculation and General Certificate of Secondary Education English Test:students' scores of the test are used as an important criterion for assessing the quality, reputation and level of emulation of these institutions.

3.5.2. Impacts of the National Matriculation and General Certificate of Secondary Education English Test on the method of teaching in the classroom

In addition to the above mentioned two goals, the National Matriculation and General Certificate of Secondary Education English Test must aim at a third one (althoughnotstated explicitly); that is, it should have positive impact on the method of teaching in the classroom. Despite the shortcomings as pointed above, it is fair to say thatthe National Matriculation and General Certificate of Secondary Education English Test has achieved the two goals it has set for. The problem that needs discussinghere liesin the third one.

Testing is not teaching; testing activities must be different from teaching activities; and testing must provide information for better and more effective teaching and learning in the classroom (cf. Davies [27]; Bachman \& Palmer [17]. But, the reality of the English classroom in Vietnamese schoolshas proved the opposite: testing is always used for teaching in the classroom. This can be seen in the fact that if in the National Matriculation and General Certificate of Secondary Education English Testthere appear phonetics, vocabulary, grammar, and reading sections designed in objective and non-objective modes, the teaching of these contents and modeswill appear in the classroom. The reality of the classroom in Vietnamese schools also shows that if in the National Matriculation and General Certificate of Secondary Education English Testthere 
appears the writing section, the writing skill will be taught in the classroom.

Teaching for the test and teaching to the test have become a common practice in schools in Vietnam today. Due to the fact that the National Matriculation and General Certificate of Secondary Education English Test does not test listening and speaking skills, teachers often do not teach these skills in the classroom. When asked, "Of the English language knowledgecomponents:phonetics, grammar, vocabulary, which do you teach the most, and of the language skills:listening, speaking, reading and writing, which do you teach the most?", the most common answer of many upper secondary school teachers of English is, "TheEnglish language knowledge components that are the most taught are vocabulary, grammar, and the most common skill that is taught is reading skill."When asked, "Can you tell me why you teach vocabulary, grammar and reading skill the most?", the common answer is, "Because these three language knowledge and skill elements are in the design of the National Matriculation and General Certificate of Secondary Education English Test, andthey account for the most points (59 out of 64) of the total test score." When asked, "Which mode do you use to teach grammar, vocabulary and reading comprehension, the objective or the nonobjective, andwhy?", the most common answer is,"We teach them in multiple-choice mode, because the 2016 National Matriculation and General Certificate of Secondary Education English Testisdesigned primarily in thismode."

It should be emphasized that teaching for thetest and teaching to the test have a very negative effect on teaching and learning in the classroom (cf. Alderson [14]). The methods of teaching for the test and teaching to the test not only narrow the contents of teaching as prescribed in the curriculum and textbooks but also deviate from the communicative orientation of English education in schools in Vietnam.Many teachers have recognised this deviation from communicativeorientation of the test and its negative impact on their teaching methods in the classroom, but due to the power and the domination of the test (cf. Shohamy [15]), they still have to teach their students how to pass the exam (teaching for the test), and because they teach their students to pass the exam, the most effective way to teach them is to rely on the format and the contents of the National Matriculation and General Certificate of Secondary Education English Test (teaching to the test). In this widespread movement of teaching for the test and teaching to the test, communicative methods do not seem to have a proper place in the foreign language classroom in Vietnamese schools.

The National Matriculation and General Certificate of Secondary Education English Test is so powerful that instead of being a part of the curriculum and having a supportive function, testing seems to have become the decisive component controlling not only the curriculum, but also the content of textbooks, the teaching methodsof teaching of the teachers, and the learning strategies of students.In line with what the teachers said in our talks, it has been observed that vocabulary, grammar and reading are the most commonly taught elementsin the classroom. It has also been observed that multiple-choice mode-the most preferred modeof design ofthe 2016 National Matriculation and General Certificate of Secondary Education English Test (and of the tests in the previous years as well)-are the most used by school teachers in Vietnam, especially those atupper secondarylevel.In their classrooms, activities such as "read and match", "read and decide on true/false information", "read and answer ", "read and discuss", "read and summarize", especially communicative skills such as listening, speaking, and creative writing (paragraph writing and essay writing) arerarely found in the classroom.

\section{Conclusion}

4.1. Summary 
In this article, driven by the fact that English language tests/examsin schools in Vietnam do not match the communicative orientation of the curriculum, textbooks and teaching methods, and that teaching and learning English in the classroomare negatively influenced by non-communicative tests, Ihave attempted to look for the source of this cause by examining the 2016 National Matriculation and General Certificate of Secondary Education English Test. Mysurveyhas shown thatthe 2016 National Matriculation and General Certificate of Secondary Education English Testhas met a number of basic criteria such asrepresentativeness of content, objectiveness, andhas succeeded in testingstudents' some aspects of English knowledge (phonetics, vocabulary and grammar) and English skills (reading and writing). My surveyhas also shown that the 2016 National Matriculation and General Certificate of Secondary Education English Test has a number of drawbacksof whichthe following seem to beprominent:

- It has focused on testing the candidate's language knowledge rather than testing his/her language skills in the sense that listening and speaking are not in its design.

- It has a shorter time span considering its nationwide proportion and the two big goals it has set for itself.

- Its modeof design is monotonous:all test items are designed inthe multiple-choice mode. This mode of design can be easily scored by machine, but it cannot test all the knowledge and skills of the English language, because "Many of the elements of any language course may not be testable in the most objective test types, such as multiple-choice, true-false and matching" (Brown, [18, 31]).

- It does not seem to take the English language knowledge and English communicative skills of an average 12 grader as the starting point for design and development. The result is that the test has appeared to be a very toughone for most of the 12 graders, with a very low degree of discrimination, and an abnormal distribution of scores(about $90 \%$ of the candidates were scoredbelow the average).

\subsection{Conclusions and recommendations}

When a test has achieved basic standards and is widely praised, people often give it a rather pompous label "a good test". A good test, according to Davies [27], Bachman \& Palmer [17] and Alderson [14], apart from achieving the goals set for it such as selection, classification and diagnosis, must have a positive impact on teaching; that is, it must help the teacher find out what parts of the instructional content (textbook) that are difficult for the student so that s/he can adjust the content and the teaching methods accordingly. Further, it must provide opportunities for the student to demonstrate his/her ability to perform language tasks in the best way possible, and motivate them to learn by measuring their accurate knowledge and skills, not to trap or deceive them. A good testmust be carefully designed, and must cover major elements of language knowledgeand communicative skills as specified in the curriculum. A good test must be designed to help students develop their strengths and learn from their weaknesses. In short, a good test must be used as a useful learning tool, and it must have a positive impacton classroom activities.Seen from the point of view of these perspectives, it can be affirmed that it will a long time before the 2016 National Matriculation and General Certificate of Secondary Education English Test can begiven the label of "a good test".

Testing often serves two goals: to distinguish students for selectionpurposes and to change students for educational purposes (Biggs [23]). From what has been analyzed, it can be affirmed thatthe 2016 National Matriculation and General Certificate of Secondary Education English Testhas achieved the first goal; but when considering it in relation to the second goal, a contradiction arises.On the one hand the test is designed in 
the multiple-choice mode (ensuring the criteria of reliability and objectivenessin terms of scoring, and thus ensuring the selection goal). On the other hand, as a result of the multiplechoice design, the test has lost some features of the criterion of validity (in that it has not yet covered what was taught and learned as defined in MoET's seven-year curriculum, andithas not yet testedhalf of the English communicative skills: listening and speaking), and, in particular, it has created undesired negative backwash effects onclassroom teaching and learning, and thus seriously challengingthe communication goal of foreign language education in schools in Vietnam. The contents and modepresent in the design of the 2016 National Matriculation and General Certificate of Secondary Education English Test are widely used in the classroom in Vietnamese schools, making learning and teaching swirled by the vortex of this non-communicative testing mode.

In the final years of the 20th century, needs analysis emerged in the design of many foreign language curricula, and this approach was adopted in many countries, including Vietnam. In this approach, the test is guided, even determined by teaching: test what is taught. According to this line of thought, if there is no teaching, testing is not necessary, and in the relationship between teaching and testing, testing seems to have an instrumental function, facilitating teaching and learning. The thought of "test what is taught" has, therefore, been extensively exploited in Vietnam. In recent years, however, due tothe negative impact of the 2016 National Matriculation and General Certificate of Secondary Education English Test, the instrumental function of testing seems to have been changed.The reality ofthe general schools in Vietnam shows that the contents and mode of the test are determining the contents and methods of teaching and learning in the classroom. Exams, especially the National Matriculation and General Certificate of Secondary Education English Testhave become a dominant force in classroom teaching and learning activities. It seems that, with what is happening in the English classroom in Vietnamese schools, the order of "test what is taught" has changed to "teach what is tested". This shift in paradigm has become a fact that "it is foolish to pretend that it does not happen" (Davies [27, 24]). Whether this change is scientifically grounded or not needs further study; but whether this change has made a positive impact on the communication goal of teaching and learning foreign languages in schools is still unsure.

The thought of "teach what is tested" is being extensively exploited in schools in Vietnam. In face of this phenomenon, many will ask, "If education of students is the ultimate goal, is it necessary for the contents and the teaching method to be patterned after the contents and mode of the test/exam?", and "If not, why there has appeared the phenomenon of 'teach what is tested?"'Like the general education of many countries in the world, selection is still one of most the important functions of general education in Vietnam. As long as this function persists, teaching for the test and teaching to the test can hardly be excluded from the teaching and learning process in the classroom.

It should be noted that in the 2017 National Matriculation and General Certificate of Secondary Education English, the writing section is not in the design, and the test now consists of only 50 items, designed entirely in the multiple-choice mode, and only testing students' English knowledge (phonetics, vocabularyand grammar) and one communicative skill (reading comprehension). Many wonder with a number of questions being raised such as: "Why a new test format?", "Which is better, the 2016 format or the 2017 one?", "What impact does this new format have on the English language teaching and learning in the Vietnamese classroom?", "How will students be affected by this change?", "Why while we are trying to improve the quality of teaching and learning English in the national education system to enable students to 
communicate in English through listening, speaking, reading and writing, the 2017 National Matriculation and General Certificate of Secondary Education English Test does not test these skills (except reading)?", "Is this is a step forwards or backwards in modern foreign language testing?"

It should be emphasized that the fact that foreign language has become a compulsory subject ingeneral schools in Vietnam, and one of the exams for conferring on the candidate general school certificate and admitting him/her to a college or university has really changed the attitudes of students, parents towards the subject, and has received more attention from the society. However, if the contents of the 2016 National Matriculation and General Certificate of Secondary Education English Testare designed in the non-communicative format: only focusing on testingthe candidate's language knowledge and reading comprehension, not testing listening and speaking skills, and especially in the 2017 National Matriculation and General Certificate of Secondary Education English Test, the writing section is not in the design, will the quality of teaching and learning English in general schools in Vietnam be improvedin the coming years? Whether students finishing upper secondary schoolswill be able to communicate in English so as to meet the requirements of Vietnamese higher education and of the labor market in the context of globalization isa question that has no definite answer.

The shortcomings I have pointed in the 2016 National Matriculation and General Certificate of Secondary Education English Test, and its negative washback effects on classroom teaching and learning require Vietnam toradically renovate its foreign language testing so that language skills should be the primary component in any foreign test/exam,especially in the National Matriculation and General Certificate of Secondary Education English Test. Only byradically renovatingthe test can foreign language education in Vietnam achieve the goal it has set foritselfin the context of globalization. Only by radically renovating the test, after but not "by 2020 will most Vietnamese young people graduating from secondary vocational schools, colleges and universities be able to use a foreign language confidently in their daily communication, their study and work in an integrated, multi-cultural and multi-lingual environment, making foreign languages a comparative advantage of the Vietnamese people to serve the cause of industrialization and modernization of the country." (The tướng Chính phủ [The Prime Minister]) [28]. And if not radically renovated in both test contents and administration, the 2016 National Matriculation and General Certificate of Secondary Education English Test will still be a challenge to and a hindrance of the goal of foreign language education in Vietnam, especially the communication goal of foreign language education in general schools.

To date, no systematic study has been conducted to assess the 2016 National Matriculation and General Certificate of Secondary Education English Test. What is presented in this article is just a few highlights, focusing on some of the key points of the test, andsome of my remarks on the test qualities are subjective, not fully substantiated by statistics.It is, therefore, of necessity to have more in-depth studies on the test to better understand its strengths and shortcomings from three perspectives: policy, theory and practice, and especially to improve the quality of the National Matriculation and General Certificate of Secondary Education English Test in the coming years.

\section{References}

[1] Hoang Van Van, The Curent Situation and the Teaching of English in Vietnam. (In) Ritsumeikan Studies of Language and Culture. Vol. 22, 2010, pp. 7-18. This paper can also be

\footnotetext{
Unless otherwise stated, I am responsible for all Vietnamese-English translations in this article.
} 
retrieved

from cube.ritsumei.ac.jp/bitstream/10367/.../LCS_22 1pp7-18_HOANG.p..., 2010.

[2] Hoàng Văn Vân, The Role of Textbooks in the Implementation of the National Project "Teaching and Learning Foreign Languages in the National Education System Period 20082020". Proceedings of the International Conference on Textbooks for the $21^{\text {th }}$ Century Held in Hanoi, 2011. Reprinted in Khoa hoc Ngoại ngũu, Số 30, Năm 2012, Trang 75-89.

[3] Hoang Van Van, The Development of the Ten-year English Textbook Series for Vietnamese Schools under the National Foreign Language 2020 Project: A Cross-cultural Collaborative Experience. Paper Addressed at the Plenary Session of the International TESOL Symposium: English Language Innovation, Implementation, and Sustainability, Held in Danang, Vietnam on 28-29 July, 2015. Reprinted in VNU Journal of Science - Foreign Studies. Vol. 31. $\mathrm{N}_{0}$. 3. 2015. pp. 1-17.

[4] Hoàng Văn Vân, Đổi mới chương trình và sách giáo khoa tiếng Anh ở trường phổ thông Việt Nam: Một giải pháp nâng cao chất lượng dạy và học môn học. Báo cáo khoa học trình bày tại phiên toàn thể Hội thảo quốc gia tổ chức tại Trường Đại học Ngoại ngữ - Đại học Quốc gia Hà Nội ngày 20 tháng 5 năm 2016. (Trong) Kỷ yếu hội thảo khoa học quốc gia 2016: Nghiên cúu và giảng dạy ngoại ngũu, ngôn ngũ \& quốc tế học tại Việt Nam. Nhà xuất bản ĐHQGHN, 2016, Trang 614-26.

[5] Bộ Giáo dục và Đào tạo,Chương trình giáo dục phổ thông môn tiếng Anh (English Curriculum for Vietnamese Schools). (Ban hành theo Quyết định Số: 16/2006/QĐ-BGDĐT ngày 05 tháng 5 năm 2006 của Bộ trưởng Bộ Giáo dục và Đào tạo), 2006.

[6] Bộ Giáo dục và Đào tạo (MoET), Chuoơng trình tiếng Anh thi điểm tiểu hoc (Pilot English Curriculum for Vietnamese Primary Schools). (Ban hành theo Quyết định Số: 3321/QĐBGDĐT ngày 12 tháng 8 năm 2010 của Bộ trưởng Bộ Giáo dục và Đào tạo), 2010.

[7] Bộ Giáo dục và Đào tạo (MoET), Chương trình giáo duc phổ thông môn tiếng Anh thi điểm cấp trung hoc co sỏ (Pilot English Curriculum for Vietnamese Lower Secondary Schools). (Ban hành theo Quyết định Số: 01/QĐ-BGDĐT ngày 03 tháng 01 năm 2012 của Bộ trưởng Bộ Giáo dục và Đào tạo), 2012.

[8] Bộ Giáo dục và Đào tạo (MoET), Chương trình giáo duc phổ thông môn tiếng Anh thi điểm cấp trung học phổ thông (Pilot English Curriculum for Vietnamese Upper Secondary Schools). (Ban hành theo Quyết định Số: 5290/QĐ-BGDĐT ngày 23 tháng 11 năm 2012 của Bộ trưởng Bộ Giáo dục và Đào tạo), 2012.

[9] Bộ Giáo dục và Đào tạo (MoET), Định dạng đề thi đánh giá năng lục sủ dụng tiếng Anh bậc 1 theo Khung năng lục ngoại ngũu 6 bậc dùng cho Việt Nam (dành cho học sinh tiểu hoc). (Ban hành theo Quyết định Số: 1479/QĐ-BGDĐT ngày 10 tháng 5 năm 2016 của Bộ trưởng Bộ Giáo dục và Đào tạo), 2016.

[10] Bộ Giáo dục và Đào tạo (MoET), Định dạng đề thi đánh giá năng lực sử dụng tiếng Anh bậc 2 theo Khung năng lực ngoại ngũu 6 bậc dùng cho Việt Nam (dành cho hoc sinh trung hoc co sở). (Ban hành theo Quyết định Số: 1475/QĐBGDĐT ngày 10 tháng 5 năm 2016 của Bộ trưởng Bộ Giáo dục và Đào tạo), 2016.

[11] Bộ Giáo dục và Đào tạo (MoET), Định dạng đề thi đánh giá năng lực sủ dụng tiếng Anh bậc 3 theo Khung năng lực ngoại ngũu 6 bậc dùng cho Việt Nam (dành cho học sinh trung họ phổ thông). (Ban hành theo Quyết định Số: 1477/QĐ-BGDĐT ngày 10 tháng 5 năm 2016 của Bộ trưởng Bộ Giáo dục và Đào tạo), 2016.

[12] Bộ Giáo dục và Đào tạo (MoET). Khung năng lục ngoại ngũ 6 bậc dùng cho Việt Nam (Six-level Foreign Language Proficiency Framework for Vietnam). (Ban hành kèm theo Thông tư Số: 01/2014/TT-BGDĐT ngày 24 tháng 01 năm 2014 của Bộ trưởng Bộ Giáo dục và Đào tạo), 2014.

[13] Bộ Giáo dục và Đào tạo (MoET), Quy chế thi trung học phổ thông quốc gia năm 2016. (Ban hành theo Thông tư Số: 01/VBHN-BGDĐT ngày 25 tháng 03 năm 2016), 2016.

[14] Alderson, J. C., The Shape of Things to Come: Will it be the Normal Distribution? (In) European Language Testing in a Global Context Proceedings of the ALTE Barcelona Conference July 2001. M. Milanovic, C. Weir, \& S. Bolton (Eds.). Cambridge: CUP. (pp. 1-26), 2004.

[15] Shohamy, E., The Power of Tests: A Critical Perspective on the Uses of Language Tests. Singapore: Peason Education, 2001.

[16] Weir, C. J., Language Testing and Validation: An Evidence-based Approach. Palgrave Macmillan, 2005.

[17] Bachman, L. F. \& A. S. Palmer, Language Testing in Practice. Oxford, England: Oxford University Press, 1996. 
[18] Brown, J. D., Testing in Language Programs. New Jersey: Prentice Hall, 1996.

[19] Kunnan, A. J., Fairness and Justice for All. (In) Fairness and Validation in Language Assessment. A. J. Kunnan (ed.). Cambridge, UK: Cambridge University Press, 2000, pp. 1-14.

[20] Kunnan, A. J., Test Fairness. (In) European Language Testing in a Global ContextProceedings of the ALTE Barcelona Conference July 2001. M. Milanovic, C. Weir, \& S. Bolton (Eds.). Cambridge: CUP, 2004, pp. 27-48.

[21] Bachman, L., Fundamental Considerations in Language Testing. Second Impression. Oxford, UK: Oxford University Press, 1991.

[22] Hughes, A., Testing for Language Teachers. Second Edition. Cambridge: Cambridge University Press, 2003.

[23] Biggs, B. (Ed.)., Testing: To Educate or to Select? Education in Hong Kong at the Crossroads. Hong Kong: Hong Kong Educational Publishing, 1996.

[24] Popham, W. J., Modern Educational Measurement. Englewood Cliffs, N. J; PrenticeHall, 1981.

[25] VnExpress (ngày 23 tháng 7 năm 2015). Phổ điểm thi THPT quốc gia năm 2015 (Score
Distributions of the 2015 General Certificate of Secondary Education Exams. Truy cập từ http://vnexpress.net/photo/tuyen-sinh/pho-diemthi-thpt-quoc-gia-nam-2015-3253155.html

[26] Phạm Việt Hà, Bài thi trung học phổ thông quốc gia môn tiếng Anh năm 2015: Phân tích trên cơ sở các tài liệu công khai. (Trong) Kỷ yếu hội thảo quốc gia: Đổi mới phuơng pháp giảng dạy và kiếm tra, đánh giá trong giáo dục ngoại ngũ. Hà Nội: Nxb Đại học Quốc gia Hà Nội, 2016, Trang 64-71.

[27] Davies, A., Principles of Language Testing. Crystal, D. \& K. Johnson (Eds.). Cambridge, Mass.: Blackwell, 1990.

[28] Thủ tướng Chính phủ (The Prime Minister), Đề án "Day và hoc ngoại ngũ trong hệ thống giáo duc quốc dân, giai đoạn 2008-2020” (Teaching and Learning Foreign Languages in the National Education System, Period 2008-2020). (Ban hành theo Quyết định Số: 1400/QĐ-TTg ngày 30 tháng 9 năm 2008 của Thủ tướng Chính phủ).

[29] VnExpress (ngày 22 tháng 7 năm 2016). Trên 90\% học sinh thi THPT quốc gia bị điểm dưới trung bình môn Tiếng Anh. Truy cập từ http://vnexpress.net/tin-tuc/giao-duc/tuyen$\sinh /$ tren-90-hoc-sinh-thi-thpt-quoc-gia-bi-diemduoi-trung-binh-mon-tieng-anh-3440828.html. 